\title{
An Assessment of the Indian Housing Finance System: Crucial Perspective
}

\author{
Mr. Ch. Hari Govinda Rao ${ }^{1}$, Dr. N. Apparao ${ }^{2}$ \\ ${ }^{1}$ Research scholar, Department of Management Studies, Vignan's Institute of Information Technology, India) \\ ${ }^{2}$ (Department of Management Studies, JNTUK University, India)
}

\begin{abstract}
House is a centre and domestic device for mankind's moral and substance development ever since the dawn of civilisation. Housing is one of the most important that we human beings need. Adequate housing is essential for human survival with dignity. There are many things that we would find difficult, if not impossible to do without good-quality housing. Housing shortage is a universal phenomenon. It is more acute in developing countries. The housing dimension in India has been changing in recent years. India has initiated so many housing reform that has taken many forms and manifestations characterized by the reduction in social allocation, cutbacks in public funding and promotion of a real estate culture in close partnership between the state and private actors. Mortgage financing markets can play an important role in stimulating affordable housing markets and improving housing quality in many countries. Unfortunately, they are often less developed in India. This lack of development often translates into lower homeownership rates or lower housing quality. Most stem from the central dilemma that the resources are always too limited and housing development heavily depend on the financial institutions such as banks, credit corporations and development banks for the supply of finance to meet their daily financial needs. Against this backdrop this paper will assess basic nuances of Indian financing system. This paper will also provide key issues, future outlook and institutional performance.
\end{abstract}

Keywords: Basic nuances of Housing, Housing Condition in India, Housing Shortage and Affordable Housing in India, Institutional Performance of housing finance in India, Key Recommendations for affordable housing.

\section{Introduction}

Since home life affects the very foundation of an individual's life, the house becomes an important part of it and Housing is one of the top priorities for most people, regardless of their income levels. Without the security and comfort of a home, there is no escape to the difficulties resulting from poverty. Adequate housing is essential for human survival with dignity. Without a right to housing, many other basic human rights will be compromised including the right to family life and privacy, the right to freedom of movement, the right to assembly and association, the right to health and the right to development. Housing is a key good for determining the cost of living. The acute shortage of housing in urban areas is due to increase in population Ruben Garrido-Yserte et al. (2012) ${ }^{10}$. Housing is one of the primary human needs and is next in importance to food and clothing. There has been increasing concern about the housing condition of the poor in the deserted slums and bustee settlements amidst the evident 'poor blindness' in housing and investment policies. The declining effectiveness of housing finance institutions coupled with economic and fiscal crises have made governments more aware of the need to promote savings, reduce subsidies and mobilize domestic resources and motivate the involvement of private financial institutions. Housing finance has risen to the top of research and policy agendas in recent years. Yet, although our understanding of the formal delivery of housing finance has improved considerably, we know far less about households' use and production of housing finance. Hence we are going to analysed the present condition of housing sector in India in this article. In the aforesaid context this paper aims to rank the importance of affordable housing in housing development. The paper will also provide current housing position in India and institutional performance of Indian housing sector and finally, the manuscript will conclude with recommendations to improve the national dwelling position.

\section{Objectives of the study}

The current work revolves around the following major objectives.

1. To study the present condition of housing sector in India such as current position of housing stock, household and its comparison with population growth etc.

2. To evaluate and contrast the evolution and recent trends in housing finance system in India.

3. To assess housing shortage and affordable housing policies in Indian housing market.

4. To give some significant recommendations to improve the affordability in housing development in India. 


\section{Literature Review}

The issue of housing and housing finance has been receiving increasing attention over the recent decade in the extant literature. There have been many studies revised on various observations on this area, few of these namely; housing is an essential element of life for most human beings polarized by Naik $(1981)^{2}$. According to J.P. Sah (2011) ${ }^{3}$, "housing is not a static but a growing problem and it was cited in Manorama Year Book (1997) ${ }^{4}$ as the modern concept of housing does not limit the idea of housing merely to the provision of shelter and it is an in an integral part of overall policy improvements of human settlements and economic development. Krishnamachari $(1980)^{5}$, as stated in the preamble of the National Housing Policy, "shelter is a basic human need and as an intrinsic part of human settlement, is closely linked with the process of overall socio-economic development.

Housing is an element of material culture, is one such devices to overcome threats against physical elements to lives and serves as an important purpose by making the provision of shelter and portrays that housing is as an important precursor of the national business cycle. In this view Some empirical exercises made on importance of housing among others Satyanarayana (1987) ${ }^{6}$, India year Book (1988) ${ }^{7}$, Andra C. Ghent and Michael T. Owyang $(2010)^{8}$, Despande $(1975)^{9}$ and Rangwala $(1977)^{10}$, Gopinath Rao $(1988)^{11}$, Dr. C. Harichandran $(1989)^{12}$, Solanki $(1989)^{13}$, highlighted the magnitude of the housing problem in our country is so heavy, that it will require considerable passage of time for the country to offer a sweet home to every family in our nation. Chacko (1989) ${ }^{14}$ was of the opinion that housing shortage in India in 1981 was 21 million units. In the beginning of the 7th five year plan in 1985, it was put as 24.7 million units. Madhav Rao et al. $(1995)^{15}$ suggested a multifaceted housing difficulty like ours requires a concrete national attempt. Amin Y. Kamete $(2011)^{16}$, opined that the housing problem has become synonymous with housing shortages. Erwin Mlecnik et al. $(2010)^{17}$ studied about the barriers and opportunities for the further diffusion of labels for highly energyefficient houses. The Major subsidised housing projects in developing countries specified by Gonzalo Lizarralde $(2011)^{18}$ Richard Harris and Ceinwen Giles $(2003)^{19}$ have done tremendous work on identified three phases in the evolution of international housing policy since 1945: public housing (1945-1960s), sites-and-services (1972-1980s), and market enabling (1980s-present. In the opinion of Nickell and Dorsey $(1976)^{20}$, the three methods of financing home ownership are cash, cash and credit and contract method. R.M. Buckley (1989) ${ }^{21}$ portrayed that Bank lending for housing finance during the period from 1972 to 1989. Munjee et al., $(1990)^{22}$ opined that credit flows into the housing sector originates therefore from formal or informal sector like, budgetary allocations, of central and state governments, financial institutions like the LIC, Unit Trust of India, Commercial Banks, provident funds and Public Sector Institutions such as HUDCO. As cited by Tiwari $(2012)^{23}$, Housing finance in India has grown at a rapid pace during the last two decades. However, the share of outstanding housing loans as a percentage of GDP stood at only $7.3 \%$ in 2005 . Hence, this study emphasizes the importance of affordable housing. Macroeconomic stability and the housing sector are inextricably linked. It is estimated that for one Indian Rupee (Rs.) invested in housing; Rs. 0.78 gets added to the gross domestic product of the country. The housing sector has strong backward and forward linkages to over 250 ancillary industries. So that this is an attempt to make a conceptual framework about Indian housing finance system.

\section{Research Methodology}

This study was designed to see the sights of an assessment of the Indian housing finance system and affordable housing development in India. The proposed study employs collection of relevant secondary data on the housing finance system pertaining India during the period 2001-11. This means and includes data relating to Indian housing finance system, housing shortage, affordable housing in India and the like. The collected data will be analysed using the suitable inferential statistical tools. There is no clear - cut definition of term 'affordable', as it is a relative concept and could have several implied meanings in different contexts (Jones Lang and Lasalle, 2012) ${ }^{24}$. Hence, firstly, it makes an attempt to about the basic definition of affordable housing. According to the RICS report on making urban housing work in India, affordability in the context of urban housing means provision of "adequate shelter" on a sustained basis, ensuring security of tenure within the means of the common urban household. According to KPMG Report on "Affordable housing"-A Key Growth Driver in the Real Estate Sector", affordable housing is defined in terms of three main parameters, namely income level, size of dwelling unit and affordability. Whilst the first two parameters' are independent of each other, the third is a dependent parameter that can be correlated to income and property prices. In particular, possessor of dwelling with an annual income level $(T O)$ of less than 1.5 lakhs $(T O<1,50,000)$ and the size of dwelling unit upto $300 \mathrm{sft}$. $(T O<300)$ were considered as Economically weaker section (EWS), greater than or equal 1.5 lakhs to less than 3 lakhs $(1,50,000 \geq T O<3,00,000)$ and the dwelling size between from $300 \mathrm{sq} f t$ to $600 \mathrm{sq} f t$ $(\geq 300 \mathrm{TO}<600)$ were tagged as Low income group (LIG) and greater than or equal 3 lakhs to less than 10 lakhs $(3,00,000 \geq T O<10,00,000)$ and at the same time the size of dwelling unit between from $600 \mathrm{sq} f \mathrm{ft}$ to 1200 sq ft. $(\geq 600$ TO < 1200) were regarded as Medium Income Group(MIG). In accordance with the guidelines amended by JNNURM Mission Directorate of MHUPA(December 2011) ${ }^{25}$, the minimum of size of 
dwelling unit is $300 \mathrm{Sq} \mathrm{ft}$ of super build-up area and minimum $269 \mathrm{sq} \mathrm{ft}(25 \mathrm{sq} \mathrm{m})$ of carpet area were considered as economically weaker section(EWS). The Low Income Group (LIG) must be contained $500 \mathrm{sq} f \mathrm{ft}$ of super build-up area and the maximum carpet area is $517 \mathrm{sq} \mathrm{ft}(48 \mathrm{sq} \mathrm{m})$. The dwelling which consists greater than or equal to 600 and less than $1200 \mathrm{sq} \mathrm{ft}(\geq 600 \mathrm{TO}<1200)$ of super buildup area and $861 \mathrm{sq} \mathrm{ft}(80 \mathrm{sq} \mathrm{m})$ of carpet area were regarded as Medium Income Group (MIG).

\section{Implications and value additions:}

The main implication of this research for scholars, banking and financial institutions and policy makers concerned with housing finance system is to recognize the development in this sector as well as identifying the possible risk associated and developing the risk mitigating policies and strategies.

\section{Housing condition In India}

Housing conditions are a key indicator of socio-economic development. The National Sample Survey Organisation (NSSO) uses the classes, katcha, semi-pucca and pucca to differentiate between the types of homes in India. A katcha house is built with non-durable materials like unburnt bricks, mud, thatches, leaves and bamboo. A pucca house is one built with permanent materials like oven burnt bricks, concrete, stone blocks, cement, iron or other metal sheets and timber. A semi-pucca house is built with both katcha and pucca materials.

\section{Table 1: Percentage Distribution of Households with Dwelling Units by Type of Structure}

\begin{tabular}{|l|c|c|c|c|c|}
\hline & $\mathbf{1 9 6 1 - 7 1}$ & $\mathbf{1 9 7 1 - 8 1}$ & $\mathbf{1 9 8 1 - 9 1}$ & $\mathbf{1 9 9 1 - 0 1}$ & 2001-11* \\
\hline Rural & & & & & \\
\hline Pucca & 19 & 23 & 32 & 36 & 49 \\
\hline Semi-Pucca & 39 & 38 & 37 & 38 & 39 \\
\hline Katcha & 42 & 40 & 35 & 28 & 19 \\
\hline $\begin{array}{l}\text { Urban } \\
\text { Including slum and squatter areas) }\end{array}$ & & & & & \\
\hline Pucca & 60 & 60 & 74 & 77 & 85 \\
\hline Semi-Pucca & 24 & 22 & 18 & 20 & 20 \\
\hline Katcha & 15 & 15 & 10 & 8 & 3.5 \\
\hline
\end{tabular}

Source: NHB Trends and Progress, 2004; National Sample Survey Organisation (NSSO) (2004).

*Projected charts

Table 1 demonstrates that the majority of households in India live in either pucca or semi-pucca homes (NHB, $2004)^{26}$. This situation has improved gradually over the years. In 2002, 36 percent of those in rural areas lived in pucca homes as opposed to 32 percent in 1993. In urban areas, the percentage of pucca homes increased to 77 percent in 2002 from 74 percent in 1993 (NSSO, 2004).

Tenure status of Housing in urban and rural area in India: The availability of shelter is a basic human need (M. Pacion, 2009) $)^{27}$. At one extreme, housing is regarded as a consumer good rather than a social entitlement. There is a preference amongst the majority of Indian households to own a home rather than opt for renting (Kerl et.al, 1977) ${ }^{28}$. In rural areas, availability of land is not as critical an issue as upgradation and improvement of the housing conditions along with civic amenities and other basic infrastructure facilities. Thus over a 40 -year period, the trend of a predominance of ownership of homes in rural areas has remained unchanged. In urban areas, the trend has distinctly changed as more people have gradually begun to opt for ownership as against rental housing (Doebele and William A., 1983) ${ }^{29}$. The reasons are two-fold: first, rent-control laws in urban areas have discouraged new rent-based units from coming into the market. Secondly, an increase in housing finance options available over the years has enabled more people to buy a home.

The tendency to own a house has shown an increasing trend among the urban households $(\mathrm{NHB}, 2004)^{30}$. The percentage of houses owned by the rural households is above 95 percent.

Table-2: Tenure status in urban and rural area in India (\%)

\begin{tabular}{|l|c|c|c|c|c|c|}
\hline & 1961 & 1971 & 1981 & 1991 & 2001 & 2011 \\
\hline URBAN & & & & & & \\
\hline Owned & 46.2 & 47.1 & 53.5 & 65.9 & 71.5 & 72.5 \\
\hline Rented & 53.8 & 52.9 & 46.5 & 34.1 & 28.5 & 27.5 \\
\hline RURAL & & & & & & \\
\hline
\end{tabular}


An Assessment Of The Indian Housing Finance System: Crucial Perspective

\begin{tabular}{|l|c|c|c|c|c|c|}
\hline Owned & 93.6 & 93.8 & 93.0 & 94.5 & 95.4 & 94.7 \\
\hline Rented & 6.4 & 6.2 & 7.0 & 5.5 & 4.6 & 5.3 \\
\hline TOTAL & & & & & & \\
\hline Owned & 69.9 & 70.45 & 73.25 & 80.2 & 83.45 & 83.6 \\
\hline Rented & 30.1 & 29.55 & 26.75 & 19.8 & 16.55 & 16.4 \\
\hline
\end{tabular}

Source: NHB Trend \& Progress Report, 2004, Census 2001
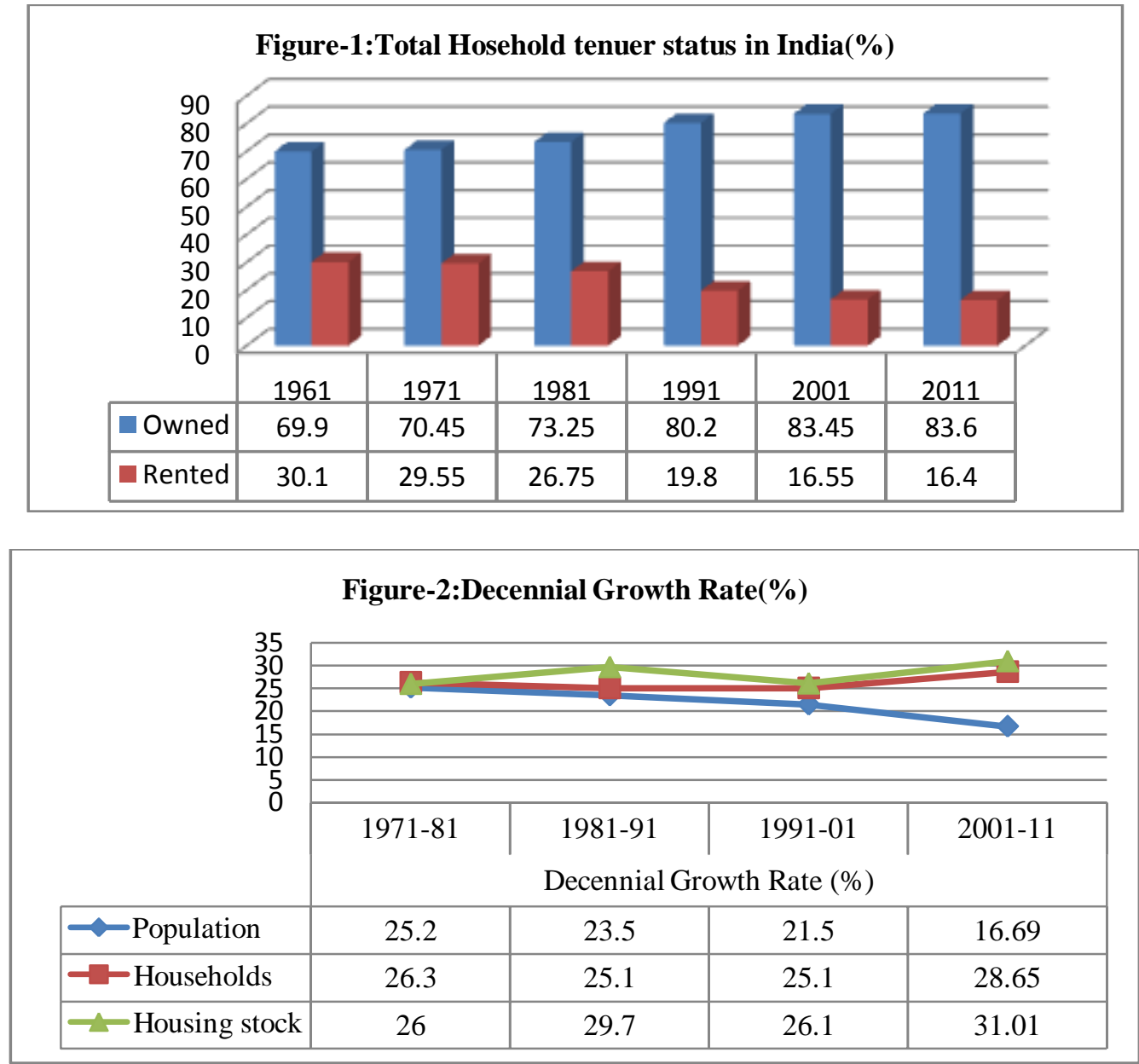

Source: NBO 2001, 2011; Census of India-2011

According to National Building Organisation (NBO) the us usable housing stock in 20 percent in 1971-81 and it was gradually increased up to 31.01 percent of total housing in India (NBO, 2001, 2011) ${ }^{31}$. Both percentage of housing stock and household are in increasing trend except during the period 1981-91. At the same time, the percentage of total population in India has recorded as in decreasing trend, it was a good sign to the future prospective (Censes of India, 2011) ${ }^{32}$.

Table-3: Variation in the Number of Census Houses

(In Crore)

\begin{tabular}{|l|c|c|c|c|c|c|c|c|c|}
\hline \multirow{2}{*}{ Census House } & \multicolumn{3}{|c|}{ Total } & \multicolumn{3}{c|}{ Rural } & \multicolumn{3}{c|}{ Urban } \\
\cline { 2 - 11 } & 2001 & 2011 & $\begin{array}{c}\text { Variati } \\
\text { on } \%\end{array}$ & 2001 & 2011 & $\begin{array}{c}\text { Variati } \\
\text { on } \%\end{array}$ & 2001 & 2011 & $\begin{array}{c}\text { Variation } \\
\%\end{array}$ \\
\hline $\begin{array}{l}\text { Number of census } \\
\text { houses }\end{array}$ & 24.9 & 33.1 & 32.8 & 17.8 & 22.1 & 24.3 & 7.2 & 11.0 & 53.8 \\
\hline $\begin{array}{l}\text { Occupied census } \\
\text { houses }\end{array}$ & 23.3 & 30.6 & 31.3 & 16.8 & 20.7 & 23.1 & 6.5 & 9.9 & 52.1 \\
\hline Used as residence & 17.9 & 23.6 & 31.7 & 12.9 & 16.0 & 23.9 & 5.0 & 7.6 & 51.6 \\
\hline $\begin{array}{l}\text { Used as residence- } \\
\text { cum-other use }\end{array}$ & 0.8 & 0.9 & 8.8 & 0.6 & 0.6 & 3.3 & 0.2 & 0.2 & 23.3 \\
\hline Housing stock & 18.7 & 24.5 & 30.7 & 13.5 & 16.6 & 23.0 & 5.2 & 7.8 & 51.0 \\
\hline
\end{tabular}

Source: Census of India-2011 
Figure-3: Variation in the Number of Census Houses - India 2001 \& 2011

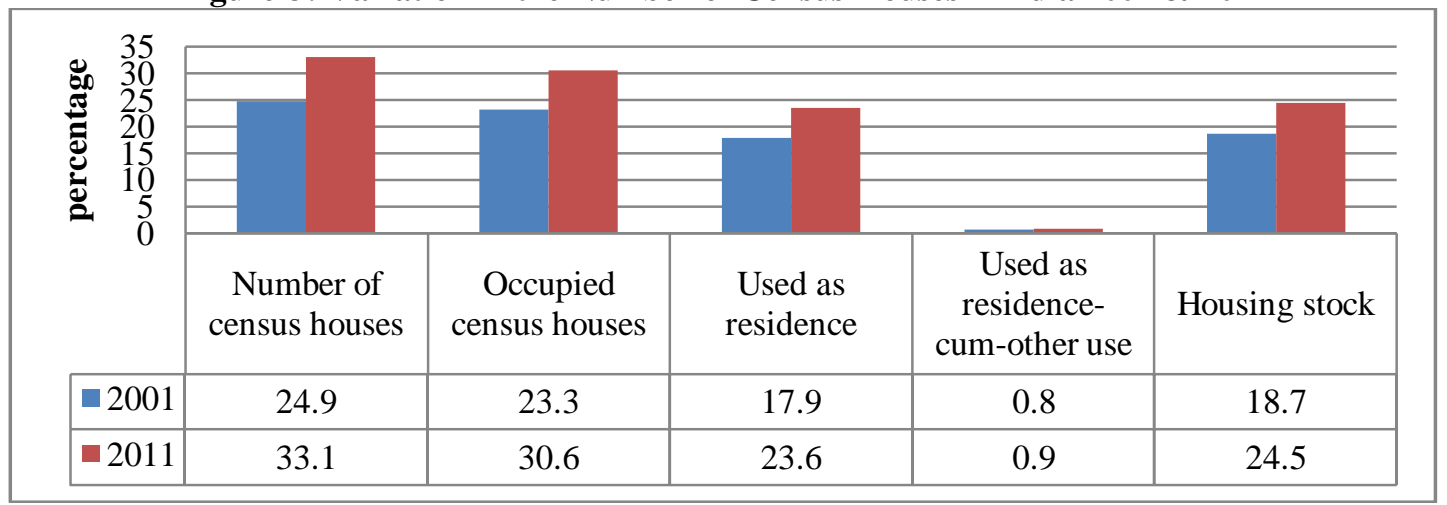

Source: Census of India-2011

From the above graphical representation (Figure-3) portrayed that the majority of households in India used their for residence purpose, i.e. 23.6 percentage of housing stock is utilized for the purpose of residential and 0.9 percentage of hoses are used for residence cum-other usage. Especially in the last decade, the occupied census housed were raised around 51.6 percentage used as residential purpose. It is good indication in the domestic housing strength of India (Census of India).

\section{Performance output of key organizations in India}

India is the second largest populous country in the world, next only to china. Home to roughly 1.1 billion people, India is the second most populous country after China and is expected to overtake it by 2030. About one in every sixth person on earth lives in India, and the growth rate of the population is still rapid. Housing finance is a relatively new concept in India comparing to other financial services that are widely available in the country since a long year back (Annual report ICRA,2011) ${ }^{33}$. However, the speedy development in housing and various housing activities have understandably led to the growth of Indian housing finance market. As a result, a number of players have barged into the market.

RBI: The Reserve Bank of India (RBI) is India's central banking institution, which controls the monetary policy and plays an important role in the development of the nation. In pursuance of National Housing Policy of Central Government, Reserve Bank of India has been facilitating the flow of credit to housing sector. Since housing has emerged as one of the sectors attracting a large quantum of bank finance, the current focus of RBI's regulation is to ensure orderly growth of housing loan portfolios of banks.

National Housing Policy: As a part of the strategy to overcome the colossal housing shortage, the Central Government adopted a comprehensive National Housing Policy which, among other things, envisaged:

i. Development of a viable and accessible institutional system for the provision of housing finance;

ii. Establishing a system where housing boards and development authorities would concentrate on acquisition and development of land and infrastructure; and

iii. Creation of conditions in which access to institutional finance is made easier and affordable for individuals for construction/buying of houses/flats. This may include outright purchase of houses/flats constructed by or under the aegis of public agencies.

HUDCO: It was in the year 1970 when Housing and Urban Development Corporation (HUDCO) was established to finance various housing and urban infrastructure activities. However, the Housing Development Finance Corporation (HDFC) was the India's first private sector housing finance company came into existence in 1977. Since then, the housing finance in India has been flying high. It's expected to grow at a growth rate of $36 \%$ in the coming years. Through its 'Niwas' scheme, HUDCO offers housing loans for the buying/constructing house/flat. Loans are also offered for renovation/extension/alteration of existing house/flat. In the financial year 2009-10 (ended on March 31, 2010), HUDCO registered a net profit of ` 495.31 crore, comparing to` 400.99 crore of the previous year.

Commercial banks: As the commercial banks started expanding housing-related disbursements, the market share also started growing up. In 2000, the Indian housing finance companies accounted for 70 per cent of the disbursements, while their collective share decreased to 36 per cent within 5 years. In 2005, banks accounted for 64 per cent of the disbursements. 
Housing Development Finance Corporation Limited (HDFC): Housing Development Finance Corporation Ltd (HDFC) is one of the leaders in the Indian housing finance market with almost $17 \%$ market share as on March 2010. Serving more than 38 lakh Indian customers as on March 2011, HDFC also offers customized solutions that fit to the need of the customer. In the FY 2010-11, it registered a net profit of ` 4528.41 crore. It also registered a net profit of ` 971 crore in the quarter ended September 30, 2011.

State Bank of India Home Finance (SBI): State Bank of India is another major player in the Indian housing finance market with 17\% of the market share, same as HDFC's share as on March 2010. The SBI Housing Loan schemes are specifically designed to meet the varied requirements of the customers. It offers home loan for various purposes including new house/flat, purchase of land, renovation/ alteration/ extension of existing house/flat etc. SBI Home Finance registered a net profit of ` 24.63 crore in the year ended March 31, 2009.

LIC Housing Finance Limited: LIC Housing Finance is another major player in housing finance sector in India with about $8 \%$ of market share. Promoted by Life Insurance Corporation of India, LICHFL has an extensive distribution network with a strong brand presence. Recently, the company has been awarded "Consumer Super brand 2009/10 Status" by Super brands Council. In the last financial year (ended on March 31,2011 ), LICHFL earned a net profit of ' 974.49 crore, comparing to ` 662.18 in the previous FY. It also registered a net profit of ` 256.50 crore in April- June quarter of 2011.

ICICI Home Finance Company Limited: ICICI is the third largest housing finance company in India with almost $13 \%$ market share. It offers various types of home loans for its customers which may have tenure up to 20 years. The home loan interest rate is connected to the ICICI Bank Floating Reference Rate (FRR/PLR). Here it can be added here that, the PLR has been increased to $17.5 \%$ from its previous rate of $17 \%$ since February 23, 2011. As on March 31, 2010, ICICI HFC has 2009 branches with an asset of ${ }^{`} 363400$ crore. The net profit of the company rose $45.19 \%$ to Rs 233.29 crore in the year ended March 2011 compared to Rs 160.68 crore profit it earned during the previous year.

IDBI Home finance Limited (IHFL): Founded in January 10, 2000, IDBI Home finance Limited has become one of the major players in the Indian housing finance market with about 4\% market share as on March 2010. It offers a range of housing financial solutions to its customers including Individual Home Loans, Home Improvement Loan, Home Extension Loan, Home Loans for NRIs, Plot Loans, and Loan against Home etc. The home loan advances of IHFL as of March 2010 were Rs 3,537 crore compared to Rs 3,089 crore in the previous year. In the financial year 2010-11, IDBI Bank registered a profit of ` 1650 crore, comparing to a net profit of ` 1031 crore in the previous financial year.

PNB Housing Finance Limited: PNB Housing Finance Limited offers a wide range of loans for purchase/construction of property to resident Indians as well as NRIs. It also offers housing finance for renovations, repairs and enhancement of immovable properties. In the last financial year ended on March 31, 2011, PNB Housing Finance Limited registered a net profit of 69.37 crore, which is 3.93\% more than the net profit of its previous financial year of 66.75 crore.

Dewan Housing Finance Corporation Limited (DHFL): Dewan Housing Finance Corporation Limited is one of the largest housing finance solution providers in India with an extensive network of 74 branches, 78 service centers and 35 camps spread across the nation. For the year ended March 31, 2011, DHFL registered a net profit of Rs. 265.13 crore which is a growth of $75.9 \%$ over net profit of Rs. 150.69 crore in the previous fiscal. In the quarter ended on September 30, 2011, DHFL earned a profit (after tax) of Rs. 71.89 crore.

GIC Housing Finance Limited: GIC Housing Finance Limited, one of the leading housing finance companies in India, was initially established as 'GIC Grih Vitta Limited' on December 12, 1989. Promoted by General Insurance Corporation of India, GIC Housing Finance Limited offers extensive range of housing finance solutions to its customers through its wide network of 24 Business Centers and 3 Collection Centers across the nation. In the financial year 2010-11, GIC Housing Finance Limited registered a profit (after tax) of Rs.113.76 crore. Furthermore, in the quarter ended June 30, 2011, it registered a profit of Rs.1756 lakhs.

Can Fin Homes Limited (CFHL): Can Fin Homes Limited is another big player in the Indian housing finance market with an extensive network of 40 branches. It is also the first and one of the biggest bank-sponsored (sponsored by Canara Bank) housing finance companies in India. In the financial year 2010-11, Can Fin Homes Limited registered a net profit of Rs. 4201.6 lakhs. It also registered a net profit of Rs.814 lakh in the quarter ended on September 30, 2011. The increase in population (more than 1027 million in 2001 with CAGR of 
2.13\% during the decade 1991-2001) has led to increase in total number of household from from 83.50 million in 1951 to 191.96 million in 2001 (with CAGR of 2.7\% during 1991-2001). However, there has also been correspondingly consistent increase in construction of additional houses. As a result, the number of occupied houses. Indian GDP has grown at $6 \%$ for the past 10 years and $8 \%$ for the last 3 years and interestingly service sector accounts for $60 \%$ of GDP (Parekh, D, 2006) ${ }^{29}$.

\section{Housing Shortage In India}

Housing shortage is a universal phenomenon (Gopinath Rao, 1988) ${ }^{34}$. It is more acute in developing countries. In India the backlog by 2000 A.0 is about 4.5 million housing units which have to be built every year. Non availability of land, price escalation of overall construction of houses, short supply of materials and lack of knowledge about several public sector institutions which offer loan at low rates of interest, are the causes of housing shortage

8.1 Severe housing shortage: According to a recent research of unitus Capital, India has a housing shortage of 40.3 million units, and demand from the low income segment constitutes a large proportion of this shortage. Assuming that five or seven people live in a unit (the Indian average is 5.5 per household), that's more than 250 million people -about a fourth of the Indian population without adequate shelter. Organization we consulted clearly confirms the demand is very high in Lower Income groups (LIG) as well as in middle class. As a result, key issues for NGOs working in new housing projects is to ensure housing units are not all booked by middle class customers and that LIG have the opportunity to apply.

8.2 Projection of the housing shortages: Population projections made by the High Powered Expert Committee were used to arrive at the number of urban households (a household size of 5 is assumed). The methodology of the Technical Group on Estimation of Housing Shortage for the 11th Five Year Plan, constituted by the Ministry of Housing and Urban Poverty Alleviation, was adopted to arrive at the housing shortages for the 12th Plan Period. The Technical Group has projected a shortage of 26.53 million housing units at the end of the 11th plan, i.e. in the year 2011-12. This shortage was taken as the base year shortage at the beginning of the 12th plan. Out of this shortage, the congestion factor contributes to 12.67 million of households and need for fresh housing contributes to 16.29 units. Based on the projected urban population in the year (HPEC, 2011) and a household size of 5, the projected number of households for the year 2016-17 is 84.4 million. Pucca housing is assumed to grow at 2.4 per cent per annum annually (basis for this) from the base year. Semi-Pucca and Kutcha housing are assumed to grow at 1.87 and 3.2 per cent per annum annually (assumed to be in the same ratio of 2012 as reported by the Technical Group of 11th plan, not clear, are the growth rates the same as assumed in the 11th plan).

8.3 Urbanization and housing shortage in India: As per 2011 census, the country had a population of 1210.98 million out of which, 377.10 million (31.16\%) lived in urban areas. During 2001-2011, the urban population of India grew at a CAGR of $2.8 \%$ resulting in the increase in level of urbanization from $27.81 \%$ to $31.16 \%$. This growing concentration of people in urban areas has led to problems of land shortage, housing shortfall and congested transit and has also severely stressed the existing basic amenities such as water, power and open spaces of the town and cities. According to the 2011 census, the housing stock in urban in India stood at 78.48 million for 78.86 million urban households. Through the gap between household and housing stock in narrowing, actual shortage is high due to a certain part of current stock being dilapidated and people living in congested dwelling. There is a gap between the demand and supply of housing (both in terms of quantity and quality) in urban in India. According to estimates of the technical group constituted by the ministry of housing and urban poverty alleviation (MHUPA, 2012) ${ }^{35}$, the urban housing shortage in the country at the end of the $10^{\text {th }}$ five years plan (2002-2007) was estimated to be 24.71 million for 66.30 million households.

Table-4: Housing Shortage in Urban India

\begin{tabular}{|c|c|c|c|c|}
\hline \multirow{2}{*}{ House } & $\begin{array}{c}\text { Monthly per } \\
\text { capital } \\
\text { expenditure }\end{array}$ & $\begin{array}{c}\text { Estimated No. } \\
\text { of households } \\
\mathbf{( 2 0 0 7 ) *}\end{array}$ & $\begin{array}{c}\text { Housing shortage } \\
\text { in million (2007) }\end{array}$ & $\begin{array}{c}\text { Percentage of } \\
\text { shortage }\end{array}$ \\
\cline { 1 - 2 } EWS & $0-3300$ & 21.81 & 21.78 & $99.9 \%$ \\
\hline LIG & $3301-7300$ & 27.57 & 2.89 & $10.5 \%$ \\
\hline MIG & $7301-14500$ & 16.92 & 0.04 & $0.2 \%$ \\
\cline { 1 - 1 } HIG & 14501 and above & 66.30 & 24.71 & $37.3 \%$ \\
\hline \multicolumn{2}{|r|}{ Total Shortage } & &
\end{tabular}

Source: MHUPA Report of the technical group (11 ${ }^{\text {th }}$ five year plan: 2007-2012) on estimation of urban housing shortage. 
The group further estimated that $88 \%$ of this shortage pertains to houses for economically weaker sections (EWS) and another 11\% for low income group (LIG). For middle and high-income groups (MIG and HIG), the estimated shortage is only 0.04 million. During $11^{\text {th }}$ five year plan, the group estimated that the total housing requirement in India cities (including backlogs) by end 2012 will be to the tune of 26.53 million dwelling units for 75.01 million households. If the current increase in backlog of housing is maintained, a minimum of 30 million additional houses will be required 2020. In this article, we will explore major issues in the development of affordable housing In India.

8.4 Massive future demand: India possesses the elements of very strong demand growth on the housing market in the coming decades. In a very conservative (and unlikely) scenario in which the average household size remains constant at the present-day level, the backlog of demand cannot be unwound and no shifts in quality take place, each year some 4.7 million housing units would have to be completed up to 2030(NCAER,2003) ${ }^{36}$. This figure is based on additional demand of roughly 2.7 million housing units and annual replacement demand of roughly 2 million dwellings. It is, however, very likely that the average household size will continue to shrink in the coming years, as sustained economic growth enables more and more young people to make a home of their own. The trend towards fewer children is ongoing. Continued progress in urbanisation will likely result in smaller household sizes. Our estimate models (see box) suggest that in 2030 an average Indian household could consist of only 3.7 to 4.7 persons. In that case, between 5.9 and 8.7 million dwellings, including replacement demand, would have to be built each year. Factoring the present supply gap of 20 to 30 million housing units into this equation, another million dwellings would need to be completed each year to achieve equilibrium on the housing market by 2030 .

\section{Affordable Housing}

International mortgage markets can play an important role in stimulating affordable housing markets and improving housing quality in many countries (Anthony B. Sanders, 2005) ${ }^{37}$ and the Challenge of housing is a simple one: the need for a healthy shelter at an affordable price (Charles L. Choguill, 2007) ${ }^{38}$, The long neglected urban India persists with an estimated 25 percent of the urban population subsists below poverty line and majority of them reside in slums and squatters. According to Ministry of Housing and Poverty Alleviation (MHUPA) India has a short fall of 24.71 million and expected to reach 26.5 million by 2012. Most of the housing shortage is for EWS and LIG Sections which does not seem to be getting translated into economic demand due to lower affordability by the poor (99 percent of the housing shortage of 24.7 million as at the end of the 10th Plan pertains to the Economically Weaker Sections (EWS) and Low Income Groups (LIG) sectors). The ever increasing demand for housing and consequent development of slums drags down the productivity of the city and its potential contribution to economic growth.

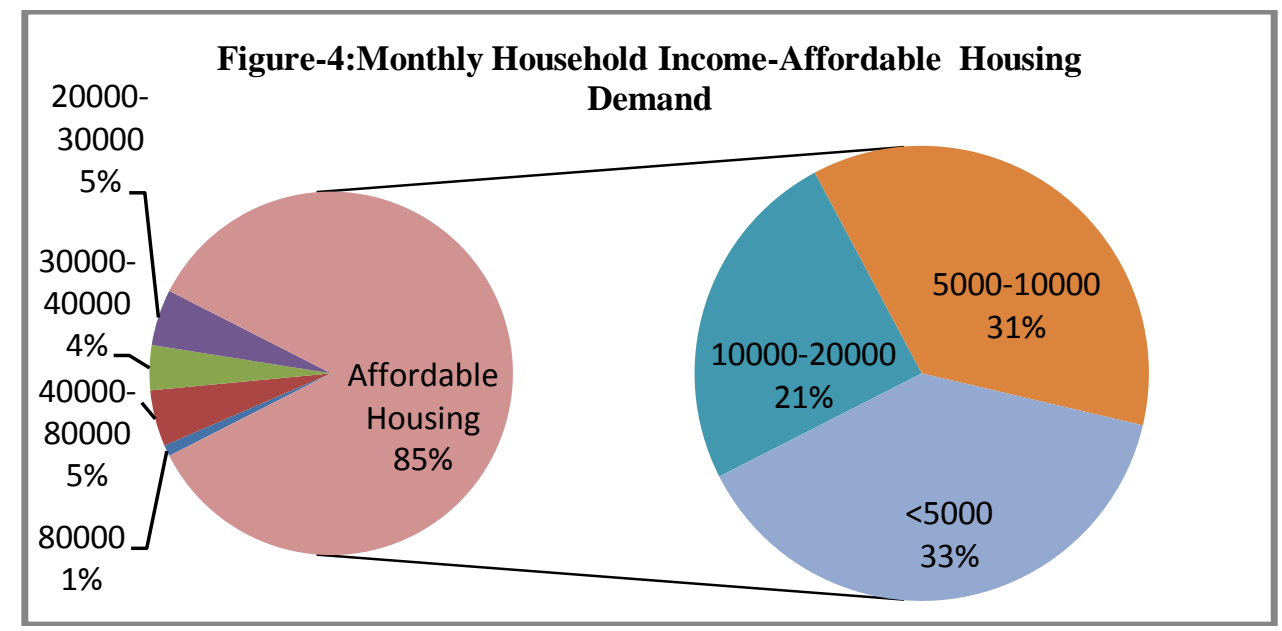

Source: Monitor

As India is the second largest country in population it requires affordable housing housing to satisfy the low income people(Ramesh Ramanathan,2010) ${ }^{39}$. The above stated graphical representation (The figure -4$)$ portrayed that aroungd $85 \%$ percentage of Housing required to fullfil the below middle class pepole in India. The people who are having greater than Rs.5000 and to 20000 Rs. income are highly needed affordable housing. Hene, Indian govternment need to concentrate develop the low income housing for the middle class people in India. 
9.1 A huge and quasi-untapped market: If we focus on population targeted by current affordable housing projects - people in urban area earning Rs. 7000 to Rs. 20000 per month (\$155 to \$440) - a Monitor's report from 2008 estimates that the demand is 21 million housing units. It means a business opportunity of Rs. $1,300,000$ crores (approximately $\$ 238$ billion). However, it is only a small share of the actual affordable housing demand because it excludes rural population and lower income groups (earning less than Rs 7,000 per month) where no profitable business models without government intervention have been identified so far.

\subsection{Continued focus on affordable housing:}

$>$ External commercial borrowings (ECBs) have been allowed as a funding option for affordable housing projects. The withholding tax rate on interest payments for these ECBs has been cut to 5 per cent from 20 per cent for the next three years. however, given weak balance sheets, many real estate developers will find it difficult to raise ECBs.

$>$ The interest rate subvention of 1 per cent of housing loan up to Rs. 1.5 million (for houses costing below Rs.2.5 million) has been extended for another year.

$>$ A credit guarantee fund is proposed to be set up to improve housing loan disbursements to the low- income category.

$>$ Rural housing fund provisions have been enhance to Rs.40 billion from 30 billion

> Service tax hike will push up prices of under-construction properties marginally.

Table-5: Low income housing in India, a big business opportunity

\begin{tabular}{|c|c|c|c|c|c|c|c|}
\hline $\begin{array}{l}\text { Monthly Household } \\
\text { Income }\end{array}$ & 80000 & $\begin{array}{l}40000- \\
80000\end{array}$ & $\begin{array}{l}30000- \\
40000\end{array}$ & $\begin{array}{l}20000- \\
30000\end{array}$ & $\begin{array}{l}10000- \\
20000\end{array}$ & $\begin{array}{l}5000- \\
10000\end{array}$ & $<5000$ \\
\hline $\begin{array}{l}\text { perentage of Housing } \\
\text { Demand (In \%) }\end{array}$ & 1 & 5 & 4 & 5 & 21 & 31 & 33 \\
\hline Price of Dwelling Unit & \multicolumn{2}{|c|}{$\begin{array}{l}\text { Greater than } 25 \\
\text { Lakhs }\end{array}$} & \multicolumn{2}{|c|}{ From Rs 10-25 Lakhs } & \multicolumn{3}{|c|}{$\begin{array}{c}\text { From Rs.3-10 } \\
\text { Lakhs }\end{array}$} \\
\hline Potential Demand & \multicolumn{2}{|c|}{$\begin{array}{l}2 \text { Million Households } \\
\text { with estimated } \\
\text { Market size of } \\
\text { Rs. } 500,000 \text { crores }\end{array}$} & \multicolumn{2}{|c|}{$\begin{array}{c}5 \text { Million Households } \\
\text { with estimated Market } \\
\text { size of Rs. } 900,000 \\
\text { Crores }\end{array}$} & \multicolumn{3}{|c|}{$\begin{array}{l}21 \text { Million Households with } \\
\text { estimated Market Size } \\
\text { Rs.1,300,000 Crores }\end{array}$} \\
\hline Market Potential & \multicolumn{2}{|c|}{$\begin{array}{c}\text { Over served and } \\
\text { demand languishing }\end{array}$} & \multicolumn{2}{|c|}{$\begin{array}{c}\text { Traditionally Small } \\
\text { developers and } \\
\text { New focus of many } \\
\text { large developers }\end{array}$} & \multicolumn{3}{|c|}{$\begin{array}{l}\text { Under served and few } \\
\text { entrants are over sold }\end{array}$} \\
\hline
\end{tabular}

Source: Monitor ; CRISIL-Budget Analsy, 2010

All these measures will support affordable housing projects (CRISIL,2010) ${ }^{40}$; however, these projects from only a small proportion of the industry currently. Indian government initiatives Rajiv Awas Yojana (RAY) to fulfill the gab in affordable housing.

\subsection{Rajiv Awas Yojana (RAY):}

Objectives: Rajiv Awas Yojana (RAY) for the slum dwellers and the urban poor envisages a 'Slumfree India' through encouraging States/Union Territories to tackle the problem of slums in a definitive manner $\left(\right.$ MHUPA2010) ${ }^{41}$. It calls for a multi-pronged approach focusing on:

$>$ Bringing existing slums within the formal system and enabling them to avail of the same level of basic amenities as the rest of the town;

$>$ Redressing the failures of the formal system that lie behind the creation of slums; and

$>$ Tackling the shortages of urban land and housing that keep shelter out of reach of the urban poor and force them to resort to extra-legal solutions in a bid to retain their sources of livelihood and employment.

The main goals of RAY will be driven and incentivized by the provision of central support for slum redevelopment and construction of affordable housing conditional to a set of reforms necessary for urban development to become inclusive. As regards reforms under RAY, security of tenure through entitlement will be critical for the overarching aim of promoting inclusive cities. Accordingly, Central Assistance under RAY will be predicated on the condition that States/UTs assign legal title to slum-dwellers over their dwelling space. The three proper reforms under JNNURM are reiterated as follows: 
i) Internal earmarking within local body budgets for basic services to the urban poor;

ii) Provision of basic services to urban poor including security of tenure at affordable prices, improved housing, water supply, sanitation and ensuring delivery of other already existing universal services of the government for education, health and social security; and

iii) Earmarking at least 20-25\% of developed land in all housing projects (both public and private agencies) for EWS/LIG category with a system of cross-subsidization.

9.4 Projection of the slum housing for RAY: The above estimates summarise the overall housing shortage in urban areas. Considering the huge backlogs of urban infrastructure as well as housing, separate estimates for housing have been prepared. Slum population projections made by the Pronob Sen Committee were used to arrive at the number of urban slum households at the end of the 12th Plan Period (a household size of 5 is assumed). Using NSSO (2008-09) data, type of housing in the slums was calculated. According to 65th round of NSSO (2008-09), pucca housing in slum areas is about 57 per cent, semi pucca is about 29 per cent, serviceable Kutcha is about 10 per cent and unserviceable Kutcha is about 3 per cent. These ratios were applied to arrive at the proportion of slum housing in each of these categories for 2011-12. All the semi pucca and kutcha housing are considered for new housing. In addition, the problem of congestion within pucca houses will also need to be addressed. The 58th Round of NSSO data shows that in the slums as many as 44 per cent of the homes, with at least one married couple, did not have separate room for the married couple. The same percentage has been applied on the 2011-12 slum housing stock to estimate the number of pucca houses with problems of congestion.

9.5 Unit cost assumptions for Affordable Housing and RAY: For the estimation purposes, unit cost of Rs. 3.5 lakh has been considered for housing and Rs. 1.2 lakh for infrastructure. For upgrading infrastructure in existing slums, a cost of Rs 70000 per household has been assumed, based on the estimates prepared by HPEC (2011). The overall investment requirement for affordable housing consist of the following elements Cost of constructing fresh housing units @Rs 3.5 lakh Cost of providing infrastructure for fresh housing units @ Rs 1.2 lakh per household Cost of upgrading infrastructure in existing slums @70000 Rs per household Cost of addressing congestion in slums as well as in non slum areas @ Rs 60,000 per housing unit.

\begin{tabular}{|l|c|c|c|c|c|}
\hline \multicolumn{7}{|c|}{ Table 6: Investment estimates for Affordable Housing } \\
\hline & $\begin{array}{c}\text { Slum } \\
\text { areas }\end{array}$ & $\begin{array}{c}\text { Non slum } \\
\text { areas }\end{array}$ & Total & $\begin{array}{c}\text { Unit } \\
\text { Cost }\end{array}$ & $\begin{array}{c}\text { Total } \\
\text { Cost }\end{array}$ \\
\hline Units & Million & Million & Million & Rs & Rs crore \\
\hline Need for fresh housing units & 10.61 & 5.68 & 16.29 & 350000 & 570150 \\
\hline Incremental housing to address congestion & 4.78 & 7.89 & 12.67 & 60000 & 76020 \\
\hline Provision of infrastructure for new housing units & 10.61 & 5.68 & 10.61 & 120000 & 127320 \\
\hline Up gradation of infrastructure in existing slums & 10.85 & 0.00 & 10.85 & 70000 & 75950 \\
\hline Housing Cost (New+ up gradation) & & & & $\mathbf{6 4 6 1 7 0}$ \\
\hline Infrastructure Cost & & & $\mathbf{2 0 3 2 7 0}$ \\
\hline Grand Total & & & 849440 \\
\hline
\end{tabular}

9.6 State Slum-free Plan of Action (POA): Rajiv Awas Yojana envisages that each State would prepare a State Slum-free Plan of Action (POA). The preparation of legislation for assignment of property rights to slum dwellers would be the first step for State POA. The POA would need to be in two parts, Part-1 regarding the upgradation of existing slums and Part-2 regarding the action to prevent new slums. In Part-1 the State would need to survey and map all exiting slums in selected cities proposed by the State for coverage under RAY. In Part-2 the Plan would need to assess the rate of growth of the city with a 20 year perspective, and based on the numbers specify the actions proposed to be taken to obtain commensurate lands or virtual lands and promote the construction of affordable EWS houses so as to stay abreast of the demand. The State POA would include the cities identified by the State and intended to be covered under RAY in five years, and their phasing. It will commit to a 'whole city' approach, so that an integrated and holistic plan is prepared for the upgradation of all existing slums, notified or non-notified, in each identified city. The POA would be expected to give primacy to a Public-Private-Partnership model that would enable it to cross-subsidies through FSI and land use concessions as much of the slum redevelopment as possible. The POA would be required to describe the model proposed to be followed in each slum, the efforts for obtaining the community's participation and the financial strategy for holistic development along with timelines State Cabinet and the commitment of the Government as to the session of the State Assembly before which it will be placed. In considering the POA, the Centre would 
particularly assess that the cities have been chosen to maximize cross-subsidization, that the extent of commitment for cross-subsidisation through PPP has been fully explored; and that the mechanisms for community participation have been clearly delineated and activated.

9.7 Conceptual Framework Slum-free City Planning: Slum-free City Cell in Urban Local Body headed by the Municipal Commissioner/Executive Officer will be primarily responsible for the preparation of Slum-free City Plans based on guidelines provided by the concerned State Government and support extended by the Nodal Agency for Rajiv Awas Yojana at the State level. The diagram in the next page provides a conceptual framework for the preparation of Slum-free City Plan.

9.8 Planning Methodology: The preparation of Slum-free City Plan will broadly involve Slum Redevelopment/Rehabilitation Plans based on

(a) Survey of all slums - notified and non-notified;

(b) Mapping of slums using the state-of-art technology;

(c) Integration of geo-spatial and socio-economic data; and

(d) Identification of development model proposed for each slum. Base maps to an appropriate scale would be a pre-requisite for the preparation of Slum Redevelopment Plan/Slum-free City Plan. States/UTs may need to proceed in the following steps for the preparation of Slum-free City Plans.

9.8.1 Securing CARTOSAT II/latest satellite images from NRSC/ISRO and preparation of base maps for the whole city and its fringes using the images;

9.8.2 Identification and inventory of all slum clusters of all descriptions in the urban agglomeration with the help of satellite image and other available data;

9.8.3 Inventory of all possible vacant lands in each zone of the urban agglomeration that could be used for slum redevelopment/ rehabilitation development purposes;

9.8.4 Development of Slum Map of every slum within the city and its fringes using GIS with CARTOSAT II images, ground level spatial data collected through total station survey, collating spatial information with respect to plot boundaries, network of basic infrastructure like roads, sewerage, storm drainage and water lines, etc and superimposing this on the satellite image and importing them into GIS platform as the first step towards the preparation of Slum Development Plans and Slum Free City Plan. This may be undertaken with the help of technical partners of NRSC/ ISRO/other technical institutions/agencies;

9.8.5 Identification and engagement of Lead NGO/CBO to guide and anchor community mobilization for the purpose of slum survey, (May be more than one $\mathrm{NGO} / \mathrm{CBO}$ in different slum zones) of the city. These Lead NGOs/CBOs should also be associated in slum survey operations and dialogues for preparation of slum level redevelopment plans;

9.8.6 Conduct of Slum Survey based on the detailed formats (with or without changes) prepared by the Ministry of Housing \& Urban Poverty Alleviation with the help of National Buildings Organisation (NBO) - after due training of trainers, training of survey personnel /canvassers and canvassing. It would be helpful for community mobilisation to pick as many canvassers from the sourced slum or nearby slum pockets;

9.8.7 Collection of bio-metric identification data of slum dwellers based on the above survey (subject to guidelines issued by Unique Identity Authority of India (UIDAI));

9.8.8 Entry of data from Slum Surveys in the web-enabled MIS application (to be provided by Ministry of HUPA), compilation and collation of data, preparation of Slum-wise, City and State Slum Survey Database and Baseline Reports. The MIS will assist in developing a robust Slum and Slum Households Information System. (Guidelines and software for development of the MIS will be issued by the Ministry of HUPA);

9.8.9 Integration of Slum MIS with GIS Maps to enable the preparation of GIS-enabled Slum Information System that is to be used for the preparation of meaningful Slum Development Plans and Slum-free City Plan using a city-wide/zone-based approach. (Guidelines and software for development of GIS platform and its integration with the MIS will be issued by the Ministry of HUPA);

9.8.10 for each slum identified, Slum Redevelopment Plan to be decided based on models like PPP development, infrastructure provision only, community-based development through Rajiv Awas Housing Societies, etc. 


\subsection{Models of Slum Redevelopment/Rehabilitation including Affordable Housing in Partnership}

\begin{tabular}{|c|c|c|c|}
\hline Model Description & $\begin{array}{c}\text { Central } \\
\text { Government } \\
\text { Support }\end{array}$ & State/ULB Support & $\begin{array}{c}\text { Contribution/Loan } \\
\text { by Individual } \\
\text { Beneficiaries }\end{array}$ \\
\hline $\begin{array}{c}\text { Affordable Housing } \\
\text { in partnership } \\
\text { Public-Public, } \\
\text { Public-Private, etc. }\end{array}$ & $\begin{array}{c}\text { Share in } \\
\text { infrastructure costs } \\
\text { of Affordable House, } \\
\text { 5\% Interest Subsidy } \\
\text { on Housing Loan }\end{array}$ & $\begin{array}{c}\text { Land Availability } \\
\text { Zoning/FSI } \\
\text { Incentives including } \\
\text { TDR, external } \\
\text { development where } \\
\text { required }\end{array}$ & $\begin{array}{c}\text { Equity Contribution } \\
\text { subsidized Housing } \\
\text { Loan with 5\% Interest } \\
\text { subsidy }\end{array}$ \\
\hline
\end{tabular}

Source: MHUPA-Rajiv Awas Yojana Guidelines for Slum-free City Planning

\section{Recommendations - Affordable Housing for susceptible Households}

10.1 Greater political priority should be attached to the housing sector: It should be recognized that the development of the housing sector could considerably contribute to economic growth, employment and poverty reduction. This stimulation could result both from the direct effects of new construction and indirect reconstruction and repair activities, as well as the effects on other sectors of the economy such as building materials, craft, utilities and housing services. Housing policy should be fully integrated into overall socioeconomic development policy.

10.2 A national housing strategy should be elaborated: Although housing stock is considered as privately owned, the Government retains the overall policy responsibility for this sector of the economy. The development and implementation of the housing strategy should therefore be led by the Ministry responsible for housing policies, the current Ministry of Economic Development, and should involve other Ministries such as Refugees and Accommodation; Justice; Finance; and Culture, Monuments Protection and Sport, as well as authorities at the municipal level.

10.3 Housing policies should be implemented by involving international donors and NGO's: Existing projects should be extended and pilot projects proposals should be developed to serve as examples and to trigger multiplier effects for developing housing policies further, following the priorities set out in the housing policy framework.

10.4 The capacity of the ministry responsible for housing should be strengthened: The department dealing with housing in the responsible Ministry, currently the Ministry of Economic Development should be provided with a clear mandate and increased staffing with adequate expertise and clear responsibilities to have an impact on the housing sector and its policies.

10.5 The cooperation between different ministries and stakeholder in the field of urban development, housing, and construction, under the lead of the med, should be intensified: Establishing a Working Group to develop the housing strategy could ensure better coordination. The experience currently made with the elaboration of the IDP strategy should be used and extended. The Working Group should be composed of members from ministries and representatives from local governments, NGOs and the private sector, and assisted by international organizations as required.

10.6 Responsibilities of local authorities related to housing should be clearly defined: In particular, the following functions should be carried out locally:

(a) Development of local housing policies (including affordable housing) which are in accordance with general State housing policy and approved spatial development plans; the process should ensure stakeholders consultations;

(b) Provision of effective and efficient management of housing and property in local ownership;

(c) Establishment of the framework for creation and monitoring the work of local housing organizations and international organizations, including donor organizations; 
(d) Ensure that the use of land in proposed projects is in accordance with approved land-use plans rests solely with the local authority's planning department.

10.7 The responsibilities of local governments related to housing should be reflected in their organizational structure: Provided that with the new legislation on local self-government local units will have increased financial means, own property and adequate staff, their structure should foresee or strengthen departments dealing with and providing policies for: (a) Urban planning and construction (permits, standards, monitoring); (b) Reconstruction and maintenance of the existing housing stock; (c) Utilities (energy, water, waste); (d) Social policy, including affordable housing (according to chapter 3 of the Law on local selfgovernment).

10.8 Tailored training activities for local employees should be scheduled: The sessions or workshops should particularly provide knowledge and good practices on, and based on, existing pilot projects: (a) Homeowners' associations; (b) Affordable housing policy options; (c) Public-private partnerships; (d) Strategic planning, project management and monitoring; (e) Fund-raising and budgeting.

\section{Conclusion}

Next to food and clothing, house as a shelter is a basic human need. It is a composite and complex good that fulfils some of the basic necessities of life. It is estimated that overall employment generation in the economy due to investment in housing/construction is eight times the direct employment. This study analyzed the present condition of housing sector in India. Housing shortage is a universal phenomenon and it is more acute in developing countries. Hence, this article has highlighted the housing shortage and the significance of affordability housing in India. This manuscript is also recommended some significant issues to the development housing sector in India. It should assist the policy makers in designing and implementing specific and well targeted policies for the overall benefit of housing sector.

\section{Acknowledgments}

This work was supported by the National Housing Board (NBO) and Census of 2001, 2011 and also MHUPA (Ministry of Urban Development Poverty Alleviation) for providing the progressive. We would like to thank Dr.Habibah-Al-Husain, the Editor, and the anonymous reviewers for their helpful comments and suggestions on earlier drafts of this article. However, all credits, interpretations, shortcomings or errors are my sole responsibility. We are also thankful to our bellowed chairman Dr.L.Rathaiah who provided research facilities and rendered timely financial support in our research; I profusely express my gratitude and wholehearted thanks to the bellowed Principal Dr.K.Alice Mary who gave me permission to carry out the survey and successful completion of this article.

\section{References}

[1] Ruben Garrido-Yserte, Elena Manas-alocon, Maria Teresa Gallo-Rivera, Housing and Cost of Living: Application To The Spanish Regions", Journal of Housing Economics, In press, accepted Manuscript,2012.

[2] Naik D.D, Housing Finance Pamphlet 163, Commerce Publication, Bombay, 1981. pp.1, 12, 15 and 18.

[3] J.P. Sah selected papers. up. Cit, 2011.

[4] Manorama Year Book, with a special feature on 50 years of Indian freedom and Democracy and development", $32^{\text {nd }}$ year of publication, , 1997, pp. 600.

[5] Krishnamachari S M, Mobilisation of Finance for Rural Housing, Yojana Publication Division, New Delhi,26 1980, 16-18.

[6] Satyanarayana C P, Housing rural poor and their living conditions, Gain Publishing House, Delhi, $1987,15$.

[7] India year Book, Director. Publication Division, Ministry of information and Broadcasting, Government of India publication, New Delhi, 1988-89, 597.

[8] Andra C. Ghent and Michael T. Owyang,, Is housing the business cycle? Evidence from US cities, Journal of Urban Economics, 67(3), 2010, 336-35.

[9] Despande, Cheap and healthy house for the middle classes in India - United Book Corporation, Pune, 1975, 1-10.

[10] Rangwala S.C., "Town P1 anning R.C. Patel”, Charotar Book Stall, 1998,51-61.

[11] Gopinath Rao, C.H., Ownership of flats: Sai Ganesh offset printers - Santhome, Madras 4, 1988, 1- 4.

[12] Dr.Harichandran C.,Housing Development Finance, Yojana Publication Division, New Delhi,35,1989,11-25

[13] Solanki, op. cit. 1989.

[14] Chacko K.O., Annual General Body meeting of cooperative societies: A tutorial review, A Seminar on 'Housing Finance, 1989.

[15] Madhav Rao, A.G. Murthy and Annamalai G, Modem Trend in housing in Developing Countries, (Oxford and IBH Publishing Company, New Delhi, 1985,341 ).

[16] Amin Y. Kamete, EXNORA's zero waste management models revisiting the urban housing crisis in Zimbabwe: Some forgotten dimensions?, Journal of Habitat International, 30(4), (2011,981-995.

[17] Erwin Mlecnik, Henk Visscher and Anke van Hal, Barriers and opportunities for labels for highly energy-efficient houses, Journal of Energy Policy, 38(8), 2010, 4592-4603.

[18] onzalo Lizarralde, Stakeholder participation and incremental housing in subsidized housing projects in Colombia and South Africa, Journal of Habitat International, 35( 2), 2011, 175-187. 
[19] Richard Harris and Ceinwen Giles, A mixed message: the agents and forms of international housing policy, 1945-1973", Journal of Habitat International, 27(2), 2003, 167-191.

[20] Nickell P and Dorsey J.M, Management in family living: John wiley and sons incorporated, New Delhi, $1976,295$.

[21] R.M. Buckley .Housing policy in developing economies: evaluating the macroeconomic impacts, Review of Urban and Regional development Studies, 2, 1989, 27-47.

[22] Munjee M. Gupta, D Mehta and Hutheesing V, Housing and housing finance in India, Shelter Conference, Journal of Housing Finance International, 1999, 26-28.

[23] Tiwari, Mortgage Market, Character and Trends: India, International Encyclopedia of Housing and Home, 2012,451-458.

[24] Jones Lang and Lasalle, 2012

[25] In accordance with the guidelines amended by JNNURM Mission Directorate of MHUPA(December 2011)

[26] Annual report ( NHB Trends and Progress, 2004; National Sample Survey Organisation (NSSO),2004).

[27] M. Pacione (2009), “International Encyclopedia of Human Geography",196-200.

[28] Kearl, James R., and Frederic S. Mishkin, The Demand for Residential Housing, and Monetary Policy”, Journal of Finance, 37, 1977, 1571-1586.

[29] Doebele and William A, Concepts of Urban Land Tenure-In Urban Land Policy: Issues and Opportunities, (New York: Oxford University Press, 1983, pp. 63-107).

[30] Annual report ( NHB Trends and Progress, 2004)

[31] Annual report (NBO 2001, 2011)

[32] Annual report (Census of India-2011)

[33] Annual report (ICRA Rating features, New Delhi, India, 2010-11).

[34] Gopinath Rao, Ownership of flats: Sai Ganesh offset printers - Santhome, 4, 1999, 1 - 4.

[35] Annual report of MHUPA (Ministry of Housing \& Urban Poverty Alleviation, Rajiv Awas Yojana Guidelines for Slum-free City Planning, New Delhi, 2012).

[36] NCAER India market demographics report, New Delhi, 2003.

[37] Anthony B. Sanders, Barriers to homeownership and housing quality: The impact of the international mortgage market, Journal of Housing Economics, 14(3), 2005, 147-152.

[38] Charles L. Choguill, The search for policies to support sustainable housing, Journal of Habitat International, 31(1), 2007, 143-149.

[39] Ramesh Ramanathan, Escale Responsible - Affordable housing in India: needs and emerging solutions, article livemint Monitor, 2010.

[40] Annual report (Monitor; CRISIL-Budget Analsysis2010)

[41] Annual report (MHUPA-Rajiv Awas Yojana (RAY) Guidelines for Slum-free City Planning,2010) 